Penelitian

\title{
Pengaruh Teat Dip dan Suplemen Temulawak terhadap Tingkat Peradangan Ambing Sapi Mastitis Subklinis
}

\section{The Effects of Curcuma Teat Dip and Supplement on The Udder Inflamation Degree of Subclinical Mastitis Cows}

\author{
Dina Amalia Solehah', Dian Wahyu Harjanti', Priyo Sambodho' \\ ${ }^{1}$ Laboratoriun Produksi Ternak Potong dan Perah, Divisi Produksi Ternak Perah \\ Departemen Peternakan, Fakultas Peternakan dan Pertanian, Universitas Diponegoo \\ J. Prof. Soedarto, SH Tembalang 50275, Semarang, Jawa Tengah Indonesia \\ *Penulis untuk korespondensi: harjantidian@gmail.com \\ Diterima 23 Januari 2020, Disetujui 19 April 2020
}

\begin{abstract}
ABSTRAK
Penelitian ini betujuan untuk mengkaji pengaruh treatment teat dipping dan pemberian suplemen pakan tepung temulawak (Curcuma xanthorriza Roxb) terhadap tingkat peradangan kelenjar ambing dan pH susu sapi perah laktasi penderita mastitis. Materi yang digunakan adalah 12 ekor sapi perah Friesian Holstein (FH) penderita mastitis subklinis. Rancangan percobaan yang digunakan adalah percobaan RAK split plot dengan 4 perlakuan dan 3 kelompok. Perlakuan yang diterapkan yaitu $\mathrm{To}=$ sebagai kontrol, $\mathrm{T} 1$ = suplemen temulawak $1 \% \mathrm{BK}, \mathrm{T} 2=$ antiseptik teat dipping temulawak $5 \%$ dan T3 = suplemen temulawak $1 \%$ BK + antiseptik teat dipping temulawak 5\%. Parameter yang diamati meliputi tingkat peradangan kelenjar ambing dengan California Mastitis Test (CMT) dan pH susu menggunakan kertas pH. Data yang diperoleh selanjutnya dianalisis menggunakan analisis ragam/ANOVA (Analysis of Variance) dan jika hasil signifikan dilakukan uji lanjut wilayah berganda Duncan Hasil penelitian menunjukkan bahwa perbedaan perlakuan dan lama perlakuan berpengaruh nyata $(\mathrm{P}<0,05)$ terhadap skor $\mathrm{CMT}$ dan tidak berpengaruh nyata terhadap $\mathrm{pH}(\mathrm{P}>0,05)$. Hasil tersebut menunjukkan bahwa sapi perah penderita mastitis yang mendapat treatment teat dipping, suplemen pakan tepung temulawaak maupun kombinasi keduanya mampu menurunkan tingkat peradangan.
\end{abstract}

Kata kunci: sapi perah, temulawak, mastitis

\begin{abstract}
This study aims to examine the effect of teat dipping treatment and supplementation of temulawak flour (Curcuma xanthorriza Roxb) on the level of inflammation of the udder gland and the $\mathrm{pH}$ of milk of lactating dairy cows with mastitis. The material used was 12 Friesian Holstein $(\mathrm{FH})$ dairy cows suffering from subclinical mastitis. The experimental design used was the RAK split plot experiment with 4 treatments and 3 groups. The treatments applied were To $=$ as a control, $\mathrm{T} 1$ = curcuma supplement $1 \% \mathrm{DM}, \mathrm{T} 2$ = curcuma teat dip $5 \%$ and $\mathrm{T} 3=$ curcuma supplement $1 \% \mathrm{DM}+$ curcuma teat dip $5 \%$. The parameters observed included the level of inflammation of the udder with the California Mastitis Test (CMT) and the $\mathrm{pH}$ of milk using $\mathrm{pH}$ paper. The data obtained were further analyzed using analysis of variance / ANOVA (Analysis of Variance) and if significant results were carried out further tests Duncan multiple area. The results of the study showed that differences in treatment and length of treatment had a significant effect $(P<0.05)$ on CMT scores and had no significant effect against $\mathrm{pH}(\mathrm{P}>0.05)$. These results indicate that mastitis dairy cows treated with teat dipping, supplementation curcuma or a combination of both can reduce the level of inflammation.
\end{abstract}

Keywords: dairy cows, curcuma, teat dipping 


\section{PENDAHULUAN}

Jumlah konsumsi susu di Indonesia semakin tinggi karena munculnya kesadaran masyarakat akan pentingnya kebutuhan protein hewani. Poduksi susu sapi perah merupakan salah satu sektor yang dapat memenuhi kebutuhan protein hewani, akan tetapi produksi susu di Indonesia hanya mampu memenuhi kebutuhan susu nasional sebesar $21 \%$ permintaan dalam negeri, sedangkan selebihnya $79 \%$ impor dari luar negeri sehingga produksi susu dalam negeri belum mampu memenuhi permintaan susu yang semakin tinggi. (Pusat Data Sistem Informasi Pertanian, 2016).

Rendahnya produksi susu dapat disebabkan oleh beberapa faktor, diantaranya faktor kesehatan. Mastitis merupakan penyakit peradangan ambing yang disebabkan oleh bakteri atau luka karena mekanis sehingga menyebabkan penurunan produksi susu dalam jumlah yang besar (Sarjowardojo, 2011). Bakteri penyebab mastitis yaitu Staphylococcus aureus, Staphylococcus epidermis, Streptococcus dysagalactiae, Streptococcus agalactiae dan Streptococcus uberis serta bakteri Caliform, Escherichia coli dan Klebsiella (Surjowardojo et al., 2016). Penyakit mastitis menyebabkan kualitas susu menjadi rendah dan $\mathrm{pH}$ susu mengalami peningkatan. Standart Total Plate Count (TPC) susu sapi segar berdasarkan SNI yaitu maksimal $1 \times 10^{6} \mathrm{cfu} / \mathrm{ml}$ dan $\mathrm{pH}$ 6,3-6,8 (BSN, 2011). Sedangkan kualitas susu yang dihasilkan oleh peternakan rakyat ratarata rendah dengan cemaran bakteri $6,6 \times 10^{6} \mathrm{cfu} / \mathrm{ml}$ (Arjadi et al., 2017).

Pencegahan yang sering dilakukan peternak yaitu menggunakan antiseptik sintesis seperti iodin, akan tetapi penggunaan antiseptik tersebut memiliki kelemahan yaitu menimbulkan rasa gatal, nyeri, rasa panas dan kemerahan (Aprilia et al., 2016). Penggunaan antiseptik sintesis dapat diganti dengan bahan-bahan herbal, salah satunya temulawak. Senyawa minyak atsiri merupakan senyawa antibakteri yang terkandung dalam temulawak (Ali el al., 2013), selain itu kurkumin merupakan senyawa polifenol sebagai antioksidan yang bermanfaat sebagai pencegah kerusakan jaringan (inflamasi) (Ahmad dan Patong, 2006 ; Asror, 2019).

Pemberian suplemen tepung temulawak sebagai pencegahan mastitis karena suplemen dapat meningkatkan daya tahan tubuh ternak. Senyawa aktif kurkumin yang terkandung dalam temulawak dapat menstimulasi imun dengan mengaktifkan sel CD4 pada sapi perah (Harjanti et al., 2019). Perlakuan teat dipping dengan melakukan pencelupan puting ke dalam antiseptik temulawak setelah pemerahan dapat mencegah masuknya bakteri pada puting yang terbuka.

Penelitian ini bertujuan untuk mengkaji tingkat peradangan ambing dan $\mathrm{pH}$ pada susu sapi perah mastitis subklinis yang diberi suplemen, antiseptik teat dipping herbal temulawak dan kombinasi antara suplemen dan antiseptik teat dipping herbal temulawak.

\section{BAHAN DAN METODE}

Materi yang digunakan dalam penelitian yaitu 12 ekor sapi perah laktasi penderita mastitis subklinis

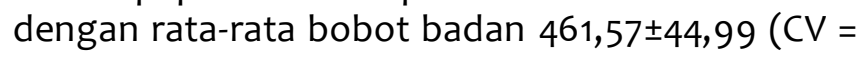
9,75\%) kg dan dibagi dalam 3 kelompok berdasarkan produksi susu yaitu produksi tinggi $(8,86-12,22 \mathrm{li}$ ter), produksi sedang $(5,09-8,85$ liter $)$ dan produksi rendah (4,14-5,08 liter) untuk rancangan percobaan. Alat yang digunakan meliputi paddle, kertas $\mathrm{pH}$ MColorpHast ${ }^{\mathrm{TM}}$ rentang 6,5-10,0 dengan sensivitas $\pm 0,3$ dan alat tulis. Bahan yang digunakan meliputi tepung temulawak, reagen California Mastitis Test (CMT), aquades, gliserin dan pakan. Pakan yang digunakan dalam penelitian berupa hijauan terdiri dari campuran rumput Kolonjono dan tebon sebanyak $30 \mathrm{~kg} / \mathrm{hari}$. Konsentrat komersial sebanyak $4 \mathrm{~kg} / \mathrm{h}$ ari. Komboran I terdiri dari kulit kopi, bekatul, ampas tahu dan kulit kacang sebanyak 24 kg diberikan sebelum dan setelah pemerahan. Komboran II terdiri ampas tahu dan konsentrat yang diberikan setelah pemerahan sebanyak $6 \mathrm{~kg}$.

\section{Rancangan Percobaan}

Rancangan percobaan yang digunakan adalah RAK Split Plot dengan 4 perlakuan dan 3 kelompok. Rancangan dibagi menjadi petak utama (main plot) dan anak petak (sub plot). Pada penelitian ini perlakuan merupakan main plot dan lama waktu perlakuan sebagai sub plot. Perlakuan yang diterapkan dalam penelitian terdiri dari :

To = Sebagai kontrol

$\mathrm{T} 1$ = Suplemen temulawak ( $1 \%$ kebutuhan BK)

$\mathrm{T}_{2}=$ =Antiseptik teat dipping temulawak (5\%)

T3 =Suplemen ( $1 \%$ kebutuhan BK) + antiseptik teat dipping temulawak (5\%)

Perlakuan To mengikuti kegiatan peternak yaitu peternak melakukan penggosokan garam pada ambing setelah pemerahan sebagai pencegahan mastitis. 


\section{Prosedur Penelitian}

Tahap pertama yang dilakukan adalah persiapan yaitu meliputi mencari materi penelitian, pembuatan antiseptik teat dipping dan menimbang suplemen pakan yang diberikan. Penelitian dilakukan di peternakan rakyat Kabubaten Semarang. Pembuatan antiseptik teat dipping herbal dengan cara merebus $5 \mathrm{~g}$ temulawak kedalam $100 \mathrm{ml}$ air selanjutnya setelah didinginkan ditambah $50 \mathrm{ml}$ gliserin untuk melembutkan puting. Pemberian suplemen $1 \%$ BK dicampurkan kedalam konsentrat.

Tahap kedua yaitu perlakuan yang dilakukan selama 30 hari. Perlakuan pemberian suplemen pakan herbal temulawak sebanyak $1 \%$ dari kebutuhan BK yang diberikan sebagian pada pagi hari dan sebagian pada sore hari

Tahap ketiga yaitu tahap pengambilan data penelitian yang dilakukan hari ke 0, 15 dan 30 untuk uji CMT dan pengambilan $\mathrm{pH}$ susu. Nilai $\mathrm{pH}$ susu diukur dari hasil pemerahan di pagi hari menggunakan kertas $\mathrm{pH}$. Kertas $\mathrm{pH}$ dicelupkan kedalam susu kemudian diamati nilai pH susu. Perubahan warna ketas $\mathrm{pH}$ merupakan indikator $\mathrm{pH}$ susu. $\mathrm{pH}$ susu ditentukan dengan menyamakan warna pada lembar indikator.

\section{Peubah yang Diamati}

California Mastitis Test (CMT), tingkat peradangan pada penelitian ini didasarkan pada hasil pengujian CMT berdasarkan skor CMT. Prosedur pengujian CMT yaitu sampel susu curahan pertama dari keempat puting sapi (kira-kira 1-2 ml) dimasukan ke dalam paddle. Setiap paddle ditambahkan reagen CMT yang sama jumlahnya dengan volume susu. Paddle dan isinya diputar secara horizontal perlahan-lahan selama kurang lebih 10 detik. Di akhir putaran, reaksi diamati dan dinilai. Setelah dilakukan pemeriksaan sesuai prosedur CMT, selanjutnya dilakukan pengamatan tingkat mastitis berdasarkan (Kurniawan et al, 2013 ; Efadri, 2010) seperti pada Tabel 1.

\section{Analisis Data}

Analisis data yang diperoleh diuji menggunakan analisis varian berdasarkan Rancangan Acak Terbagi (Split Plot) pada RAK dengan membandingkan nilai F hitung dengan $\mathrm{F}$ tabel pada taraf $1 \%$ dan $5 \%$. Apabila terdapat pengaruh yang signifikan dilanjutkan uji Duncan.

\section{HASIL}

Hasil penelitian yang dapat dilihat pada Tabel 2, menunjukkan bahwa tidak terjadi interaksi yang nyata $(P>0,05)$ antara perlakuan dan lama waktu perlakuan terhadap sapi mastitis subklinis yang mendapat treatment teat dipping dan pemberian suplemen pakan temulawak. Hasil perlakuan menunjukkan terdapat perbedaan yang nyata $(P<0,01)$ pada sapi mastitis subklinis yang mendapat treatment teat dipping dan pemberian suplemen pakan temulawak terhadap skor CMT karena penurunan skor CMT pada kelompok T1, T2, T3 lebih tinggi dibandingkan To. Hasil rata-rata lama waktu perlakuan menunjukkan perbedaan yang nyata $(P<0,05)$ terhadap skor CMT karena terdapat kecenderungan penurunan sel radang mulai $\mathrm{H} 15$ dan turun pada $\mathrm{H} 30$.

Hasil penelitian dapat dilihat pada Tabel 3, menunjukkan bahwa tidak terjadi interaksi yang nyata $(P>0,05)$ antara perlakuan dan lama waktu perlakuan terhadap sapi mastitis subklinis yang mendapat treatment teat dipping dan pemberian suplemen pakan temulawak. Hasil perlakuan menu njukkan tidakterdapat perbedaan yang nyata $(P>0,05)$

Tabel 1 Interpretasi berdasarkan CMT

\begin{tabular}{cclc}
\hline Skor CMT & Jumlah Sel Somatik & \multicolumn{1}{c}{ Deskripsi } & Konversi \\
\hline $\mathrm{N}$ & $0-480.000$ & Tidak terjadi pengentalan & 0 \\
(Negatif) & 640.000 & Sedikit pengentalan & 1 \\
T & & & 2 \\
1 & 660.000 & Pengentalan berbeda, belum terbentuk gel & 3 \\
2 & 2.400 .000 & Mengental dan membentuk gel di dasar cangkir & 4 \\
\hline
\end{tabular}


Tabel 2 Skor CMT sapi perah

\begin{tabular}{ccccc}
\hline \multirow{2}{*}{ Perrlakuan } & \multicolumn{3}{c}{ Hari } & Rata- \\
\cline { 2 - 4 } & Ho & H15 & H30 & rata \\
\hline To & 2,08 & 1,78 & 1,89 & $1,91^{\mathrm{a}}$ \\
T1 & 1,44 & 1,45 & 1,11 & $1,33^{\mathrm{b}}$ \\
T2 & 2,19 & 1,94 & 1,67 & $1,93^{\mathrm{a}}$ \\
T3 & 2,33 & 2,33 & 2,08 & $2,25^{\mathrm{a}}$ \\
\hline Rata-rata & $2,01^{\mathrm{a}}$ & $1,88^{\mathrm{ab}}$ & $1,69^{\mathrm{b}}$ \\
\hline Keterangan : \\
abSuperskrip yang berbeda pada baris yang sama menunjuk- \\
kan perbedaan yang nyata (P<0,05) \\
abSuperskrip yang berbeda pada kolom yang sama menunjuk- \\
kan perbedaan yang nyata (P<0,01)
\end{tabular}

Perlakuan $\mathrm{T} 1, \mathrm{~T} 2$ dan $\mathrm{T} 3$ dengan treatment teat dipping dan pemberian suplemen pakan temulawak memiliki persentase penurunan yang lebih tinggi $(\mathrm{P}<0,05)$ jika dibandingkan dengan To yang mendapat perlakuan menggunakan garam (Tabel 2). Perlakuan suplementasi temulawak mampu menurunkan skor CMT karena senyawa aktif yang terkandung dalam temulawak dapat meningkatkan imun ternak. Sel normal dalam ambing diantaranya yaitu PMN, limfosit dan sel epitel. Apabila terjadi infeksi maka sel tersebut akan menghalangi bakteri masuk dengan meningkatkan daya fagositosis terhadap bakteri. Penilitian Nickerson et al. (2019) bahwa

Tabel 3 Nilai pH Susu

\begin{tabular}{ccccc}
\hline \multirow{2}{*}{ Perrlakuan } & \multicolumn{3}{c}{ Hari } & Rata-rata \\
\cline { 2 - 4 } & Ho & H15 & H30 & \\
\hline To & 6,63 & 6,57 & 6,60 & 6,60 \\
T1 & 6,57 & 6,60 & 6,60 & 6,59 \\
T2 & 6,80 & 6,60 & 6,60 & 6,67 \\
T3 & 6,60 & 6,57 & 6,60 & 6,59 \\
\hline Rata-rata & 6,65 & 6,58 & 6,60 & \\
\hline
\end{tabular}

pada sapi mastitis subklinis yang mendapat treatment teat dipping dan pemberian suplemen pakan temulawak terhadap $\mathrm{pH}$. Hasil rata-rata lama waktu perlakuan menunjukkan tidak terdapat perbedaan yang nyata $(P>0,05)$.

\section{PEMBAHASAN}

Penurunan skor CMT menunjukkan bahwa diduga terdapat penurunan tingkat peradangan pada ambing, karena tingkat peradangan ambing dapat disebabkan oleh bakteri yang masuk ke dalam puting yang dapat mengakibatkan peradangan ambing (Prasetyani et al., 2017). Penurunan skor CMT karena kandungan senyawa aktif yang terkandung dalam temulawak. Temulawak mengandung senyawa aktif kukumin dan minyak atsiri yang berkhasiat sebagai antiinflamasi, antioksidan dan juga sebagai antibakteri (Syamsuddin et al., 2019). Temulawak mempunyai dua senyawa aktif yang penting yaitu kurkumin dan minyak atsiri, senyawa tersebut berfungsi sebagai antiinflamasi (Harjanti et al., 2019). pakan tambahan dapat meningkatkan aktivitas fagositosis polymorphonuklear (PMN) terhadap bakteri Eschericia coli dan Staphylococcus aureus. Makrofag merupakan sel predominant yang ada pada ambing, makrofag akan bermigrasi ke jaringan melalui stimulus inflammatory (Mehrzad el al., 2010). Perlakuan Teat dipping temulawak mampu menurunkan tingkat peradangan karena teat dipping dapat melapisi ambing dengan zat aktif larutan tersebut sehingga bakteri penyebab infeksi ambing tidak dapat masuk dan berkembang (Priono et al., 2016).

Perlakuan mampu menurunkan skor CMT pada hari ke-15, akan tetapi penurunan skor CMT lebih terlihat apabila perlakuan dilakukan selama 30 hari (Tabel 2). Penurunan skor CMT efek dari kerja senyawa aktif yang terkandung dalam temulawak. Senyawa kurkumin yang terkandung dalam temulawak berperan sebagai antiinflamasi (Harjanti et al., 2019). Senyawa minyak atisiri sebagai antibakteri dapat mengganggu proses pembentukan membrane ataupun dinding sel bakteri sehingga tidak terbentuk sempurna (Ali el al., 2013).

Berdasarkan hasil penelitian (Tabel 3) nilai pH yang diperoleh masih dalam rentang $\mathrm{pH}$ normal susu 
segar berdasarkan SNI. Nilai pH sangat variatif yang dapat dipengaruhi oleh beberapa hal. Sapi mastitis yang memiliki nilai $\mathrm{pH}$ basa disebabkan karena terdapat peradangan pada ambing sehingga permeabilitas membran sel terganggu yang menyebabkan $\mathrm{NaCl}$ naik dan sel leukosit keluar (Mahpudin et al., 2017). Penelitian Sudarwanto dan Sudarnika (2008) $\mathrm{pH}$ susu yang menderita mastitis yaitu berada pada rentang 6,3-7,2, sapi mastitis yang disebabkan oleh mikroorganisme Streptococcus agalactiae atau Streptococcus dysgalactiae memiliki nilai $\mathrm{pH}$ yang sedikit turun. Penelitian tersebut sama dengan penelitian ini bahwa nilai $\mathrm{pH}$ pada rentang sapi mastitis subklinis meskipun secara SNI Nomor 3141.1.:2011 diterima sebagai pH susu segar, akan tetapi dalam penelitian ini tidak spesifik meniliti masing-masing bakteri penyebab mastitis.

Kesimpulan dari penelitian ini yaitu treatment teat dipping, pemberian suplemen pakan temulawak terpisah maupun kombinasi keduanya mampu menurunkan tingkat peradangan pada ambing sapi perah yang menderita mastitis subklinis.

\section{UCAPAN TERIMA KASIH}

Terima kasih kepada Universitas Diponegoro yang telah mendanai penelitian ini melalui Program Dana Hibah Universitas Diponegoro tahun 2018.

"Penulis menyatakan tidak ada konflik kepentingan dengan pihak-pihak yang terkait dalam penelitian ini".

\section{DAFTAR PUSTAKA}

Ahmad, A dan Patong, R. 2006. Aktivitas antikanker senyawa bahan alam kurkumin dan analognya pada tingkat molecular. Kedokteran Yarsi. 14: 158-163. Ali, S., Baharuddin, M dan Sappewali, S. (2013). Pengujian aktivitas minyak atsirijahe (zingibe offcinale roscoe) terhadap bakteri Staphylococcus Aureus dan Escherichia Coli. Al-kimia. 1: 18 - 31.

Aprilia, P. R., S. A. B. Santoso dan D. W. Harjanti. 2016. Jumlah Staphylococcus aureus dan kandungan nutrient susu akibat dipping putting menggunakan ekstrak daun belimbing wuluh (Averrhoa belimbi Linn) pada sapi perah penderita mastitis subklinis. J. Ilmu-ilmu Peternakan $26: 43-51$.
Arjadi, L., Nurwantoro dan D. W. Harjanti. 2017. Evaluasi cemaran bakteri susu yang ditinjau melalui rantai distribusi susu dari petemak hingga KUD di kabupaten Boyolali. Ilmu-ilmu Pertanian. 13:1-10. Asror, M.Z., 2019. Produksi dan Kualitas Susu Akibat Teat Dipping dengan Ekstrak Daun Ubi Jalar Merah (Ipomoea batatas Poir) pada Sapi Perah Penderita Mastitis Subklinis. Skripsi. Fakultas Peternakan dan Pertanian. Universitas Diponegoro. Semarang.

Badan Standardisasi Nasional. 2011. [SNI] Standar Nasional Indonesia Nomor 3141.1.:2011. Tentang Syarat Mutu Susu Segar. Jakarta.

Efadri, S. 2010. California mastitis test (CMT). http://susukamb-ingku.com /cmt\%2otest.susu./ kambing.html. 2 Maret 2013

Harjanti, D. W., F. Wahyono and D. N. Afifah. 2019. Milk Production and Milk Quality of Sub-clinical Mastitis Cows Feed With Different Supplementation of Herbal in the Diet. IOP Conf Series : Earth and Environmental Science 250 (2019) 012062.

Indriani, A. P., A. Muktiani dan E. Pangestu. 2013. Konsumsi dan produksi protein susu sapi perah laktasi yang diberi suplemen temulawak (curcuma xanthoriza) dan seng proteinat. Animal Agriculture. 2: 128-135.

Kurniawan, I., Sarwiyono dan P. Surjowardojo. 2013. Pengaruh teat dipping menggunakan dekok daun kersen (Muntingia calabura L.) terhadap tingkat kejadian mastitis. Ilmu - Ilmu Peternakan 23: 27-31.

Mahpudin, F. Wahyono dan D. W. Harjanti. 2017. Efektivitas ekstrak daun babadotan sebagai green antiseptic untuk pencelup putting sapi perah. Agripet. 17: 15-23.

Mehrzad, J., M. Paape dan C. Burvenich. 2010. Role of neutrophils in protection of udder from infection in high yielding dairy cows. Iranian Journal of Veterinary Research. 11: 102-114.

Nickerson, S. C., F. M. Kautz., L. O. Ely., A. D. Rowson., D. J. Hurley., J. D. Chapman dan D. J. Mclean. 2019. Effect of an immunodulatory feed additive on intramamary infection prevelance and somatic cell count in a dairy herd experiencing major health issues. Research in veterinary science. 124: 186-190.

Priono, D., E. Kusumanti dan D. W. Harjanti. 2016. Jumlah bakteri staphylococcus aureus dan skor California mastitis test (CMT) pada susu kambing peranakan etawa akibat dipping ekstrak daun babadotan (Ageratum conyzoides L.). Ilmu-ilmu Peternakan. 26: 52-57. 
Prasetyani, D. R., C. Budiarti dan D. W. Harjanti. 2017. Efektivitas daun kersen (Muntinga calaburata L) dalam menurunkan jumlah bakteri dalam susu dan peradangan ambing sapi perah. Ilmu-ilmu Peternakan. 12: $10-16$.

Pusat Data dan Sistem Informasi Pertanian. 2016. Outlook Susu Komoditas Pertanian Subsektor Peternakan. Kementerian Pertanian Indonesia, Jakarta.

Sudarwanto, M dan E. Sudarnika. 2008. Hubungan antara $\mathrm{pH}$ susu dengan jumlah sel somatic sebagai parameter mastitis subklinik. Media Petenakan. $31: 107-113$.
Surjowardojo, Puguh. 2011. Tingkat kejadian mastitis dengan whiteside test dan produksi susu sapi perah friesien Holstein. Ternak Tropika 12 : 46 - 44.

Surjowardojo, P., T. E. Susilorini dan V. Benarivo. 2016. Daya hambat dekok kulit apel manalagi (Malus sylvestris Mill) terhadap pertumbuhan Escherichia coli dan Streptococcus agalactiae penyebab mastitis pada sapi perah. Ternak Tropika. 17: 11-21.

Syamsuddin, R. A. M. R., F. Perdana., F. S. Mutiaz., F. Galuh., A. P. A. Rina., N. D. Cahyani., S. Aprilya., R. Yanti dan F. Khendri. 2019. Tanaman temulawak (Curcuma xanthorriza Roxb) sebagai obat tradisional. Ilmiah Farmako Bahari. 10: 61-65. 